Article

\title{
Climate Change and Its Impacts on Water Resources in the Bandama Basin, Côte D'ivoire
}

\author{
Gneneyougo Emile Soro ${ }^{1, *}$, Affoué Berthe Yao ${ }^{2}$, Yao Morton Kouame ${ }^{1}$ and Tié Albert Goula Bi ${ }^{1}$ \\ 1 Unit Training and Research in Science and Environment Management, University Nangui Abrogoua, \\ 02 BP 801 Abidjan 02, Abidjan, Ivory Coast; mortonkouame@ymail.com (Y.M.K.); \\ goulaba2002@yahoo.fr (T.A.G.B.) \\ 2 Unit Training and Research in Environment, Université Lorougnon Guédé, BP150 Daloa, Daloa, Ivory Coast; \\ y_berth@yahoo.fr \\ * Correspondence: ge_soro@yahoo.fr; Tel.: +225-737-1070
}

Academic Editor: Heejun Chang

Received: 28 December 2016; Accepted: 1 March 2017; Published: 4 March 2017

\begin{abstract}
This study aims to assess future trends in monthly rainfall and temperature and its impacts on surface and groundwater resources in the Bandama basin. The Bandama river is one of the four major rivers of Côte d'Ivoire. Historical data from 14 meteorological and three hydrological stations were used. Simulation results for future climate from HadGEM2-ES model under representative concentration pathway (RCP) 4.5 and RCP 8.5 scenarios indicate that the annual temperature may increase from $1.2{ }^{\circ} \mathrm{C}$ to $3{ }^{\circ} \mathrm{C}$. These increases will be greater in the north than in the south of the basin. The monthly rainfall may decrease from December to April in the future. During this period, it is projected to decrease by $3 \%$ to $42 \%$ at all horizons under RCP 4.5 and by $5 \%$ to $47 \%$ under RCP 8.5 . These variations will have cause an increase in surface and groundwater resources during the three periods (2006-2035; 2041-2060; 2066-2085) under the RCP 4.5 scenario. On the other side, these water resources may decrease for all horizons under RCP 8.5 in the Bandama basin.
\end{abstract}

Keywords: rainfall; temperature; runoff; groundwater recharge; Bandama river

\section{Introduction}

Climate change is inevitably resulting in changes in climate variability and in the frequency, intensity, spatial extent, duration, and timing of extreme weather and climate events [1]. The works of $[2,3]$ showed that $46 \%$ of cultivated areas in the world are not suitable for rained agriculture because of climate changes and other meteorological conditions. Many studies have concluded that the impacts of climate change will not be equally shared among the population of the world [4-7]. The distribution of impacts will vary as both the ability to respond to impacts and the availability of resources with which to do so vary across nations [8]. There is high confidence that developing countries will be more vulnerable to climate change than developed countries, and there is medium confidence that climate change would exacerbate income inequalities between and within countries [7]. Sub-Saharan Africa is considered the most vulnerable to the impacts of climate change because of its high dependence on agriculture and natural resources, warmer baseline climates, low precipitation, and limited ability to adapt [9]. Several studies have shown that surface water and groundwater evolutions over the past decades in Sub-Saharan Africa have been strongly affected by rainfall variations. Climate models project important climate changes for the 21st century in West Africa as well as in the rest of the world, with potential impacts on the hydrological cycle [10]. This vulnerability is also due to the fact that the current climate is already severe, present information is not sufficient, and technological change has been slowest in Sub-Saharan Africa [11]. 
Côte d'Ivoire, located in West Africa is no exception to this situation because its economy is based on rain-fed agriculture and it has a strong dependence on river flow for the power generation and fisheries. In this country, the impacts of climate change have led to recurrent droughts, changes in rain amount distribution, reduction of arable land, coastal erosion, and flooding [12]. Many studies on the impacts of climate variability were carried out in Côte d'Ivoire [13-18]. Few studies have been conducted to investigate the impact of climate change on the water resources in the Bandama basin, despite the increase in water requirements for water supply of populations, agriculture, livestock, mining, and hydroelectric dams. Moreover, the few previous studies have used the Special Report on Emissions Scenarios (SRES) that explicitly consider the effects of prescribed levels of emissions into the atmosphere. However, there was enormous uncertainty regarding contributing factors such as population growth, economic development, and technological advances, hence, the move towards representative concentration pathways (RCPs) in this study. The better understanding of potential future changes on water resources is fundamental to inform populations in order to increase awareness and to support the development of adaptation strategies on the Bandama basin. This study examined how projected changes in temperature and precipitation regimes impact simulated runoff and groundwater recharge in the Bandama catchment using statistical downscaled climatological data.

\section{Data and Methods}

\subsection{Study Area}

Figure 1 shows the Bandama basin located in Côte d'Ivoire. The Bandama river is one of the four major rivers of the country. Its source is located north of Côte d'Ivoire between Korhogo and Boundiali. There are three major tributaries: White Bandama $\left(22,293 \mathrm{~km}^{2}\right), \mathrm{N}^{\prime} \mathrm{zi}\left(3500 \mathrm{~km}^{2}\right)$, and Marahoue $\left(19,800 \mathrm{~km}^{2}\right)$. The Bandama basin spreads over three different climatic and hydrographic regions because its regime follows the rainy season. Its northern part is characterized by dry sub-tropical climate (between $1000 \mathrm{~mm}$ and $1700 \mathrm{~mm}$ ). This area has a unimodal rainfall distribution or pattern with distinct wet (rainy) and dry seasons. The central (equatorial climate) and southern (humid equatorial climate) parts of the basin are characterized by two rainy seasons. In the equatorial climate, the annual rainfall is greater than $1500 \mathrm{~mm}$. The amount of rainfall is higher in the humid equatorial climate, with a yearly mean of $1800 \mathrm{~mm}$. As described in previous studies [19,20], the lithology is characterized by the Birimian formations (volcanic, volcanogenic, and sedimentary formations) and granitoid Eburnean comprised of granitic solid masses in which several generations of granites are distinguished. Alterites and fracture aquifers provide a year groundwater supply linked to the underground grid of fractures [21]. Previous studies [22,23] have shown that groundwater recharge is highly dependent on rainfall and varies between $50 \mathrm{~mm}$ and $354 \mathrm{~mm}$ in the Bandama basin. Vegetation cover in the Bandama catchment varies from north (savannah) to south (forest). Topography of the Bandama catchment is gentle, with a maximum elevation of $809 \mathrm{~m}$ above sea level.

\subsection{Dataset}

\subsubsection{Historical Time Series Data}

Historical meteorological and hydrological data were collected from the Department of meteorology and hydraulic infrastructures division, Government of Côte d'Ivoire. In this study, the climate data include details of rainfall, temperature, and the potential evapotranspiration. The hydrological data includes mean monthly flow of the Bandama river and its tributaries (Marahoue and N'zi). The stations were selected to provide a good spatial coverage of the different climatic areas across in the Bandama basin (Figure 2). The meteorological stations outside the watershed were used because the climatic parameters measured at these stations influence the flows on the basin. The list of historical data used is presented in Table 1. 
Table 1. Characteristics of the selected stations.

\begin{tabular}{|c|c|c|c|c|c|}
\hline Code & Station & Data & $\begin{array}{c}\text { Longitude } \\
\text { (Decimal Degree) }\end{array}$ & $\begin{array}{c}\text { Latitude } \\
\text { (Decimal Degree) }\end{array}$ & $\begin{array}{c}\text { Data } \\
\text { Availability }\end{array}$ \\
\hline 1090012000 & Korhogo & \multirow{14}{*}{ Meteorological } & -5.61 & 9.41 & 1971-2005 \\
\hline 1090006400 & Boundiali & & -6.46 & 9.51 & 1922-2005 \\
\hline 1090005600 & Bouaké & & -5.06 & 7.73 & $1966-2005$ \\
\hline 1090018700 & Tafiré & & -5.15 & 9.06 & $1950-2005$ \\
\hline 1090007300 & Dabakala & & -4.43 & 8.38 & $1945-2005$ \\
\hline 1090015100 & M'Bahiakro & & -4.33 & 7.45 & $1944-2005$ \\
\hline 1090022200 & Zuénoula & & -6.05 & 7.41 & $1953-2005$ \\
\hline 1090009100 & Dimbokro & & -4.70 & 6.65 & $1921-2005$ \\
\hline 1090016900 & Oumé & & -5.41 & 6.36 & $1944-2005$ \\
\hline 1090005200 & Bouaflé & & -5.75 & 6.98 & $1924-2005$ \\
\hline 1090010300 & Gagnoa & & -5.95 & 6.13 & $1922-2005$ \\
\hline 1090019600 & Tiassalé & & -4.83 & 5.88 & $1959-2005$ \\
\hline 1090000100 & Abidjan & & -3.93 & 5.25 & $1961-2005$ \\
\hline 1090010000 & Ferkessédougou & & -5.20 & 9.60 & $1961-2005$ \\
\hline 1090101006 & Marahoué & \multirow{3}{*}{ Hydrological } & -5.75 & 6.97 & $1954-2005$ \\
\hline 1090102515 & $\mathrm{~N}^{\prime} \mathrm{Zi}$ & & -4.81 & 6.00 & $1953-2005$ \\
\hline 1090100154 & Tiassalé & & -4.82 & 5.89 & $1954-2005$ \\
\hline
\end{tabular}

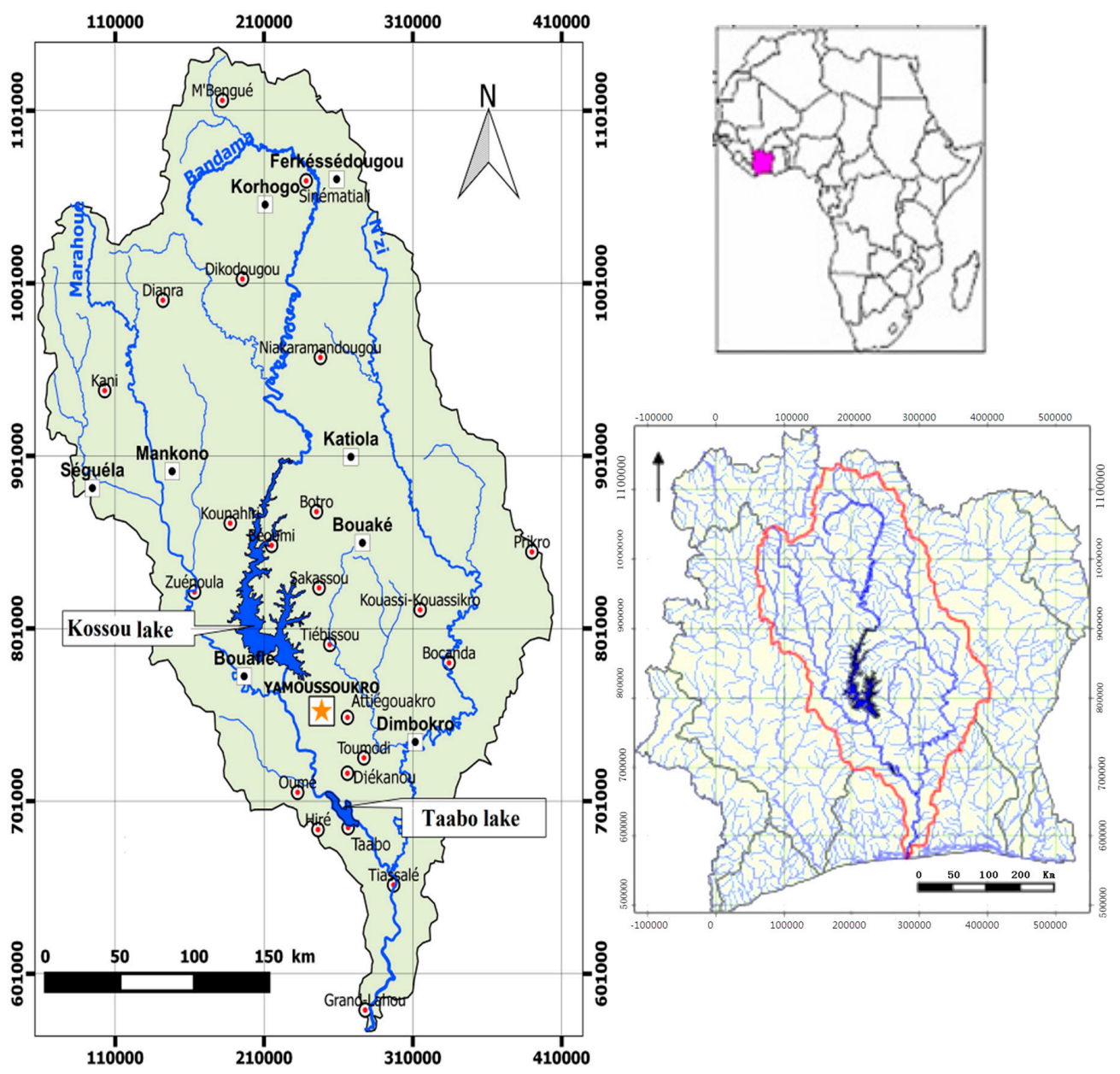

Figure 1. Geographical location of the study area. 


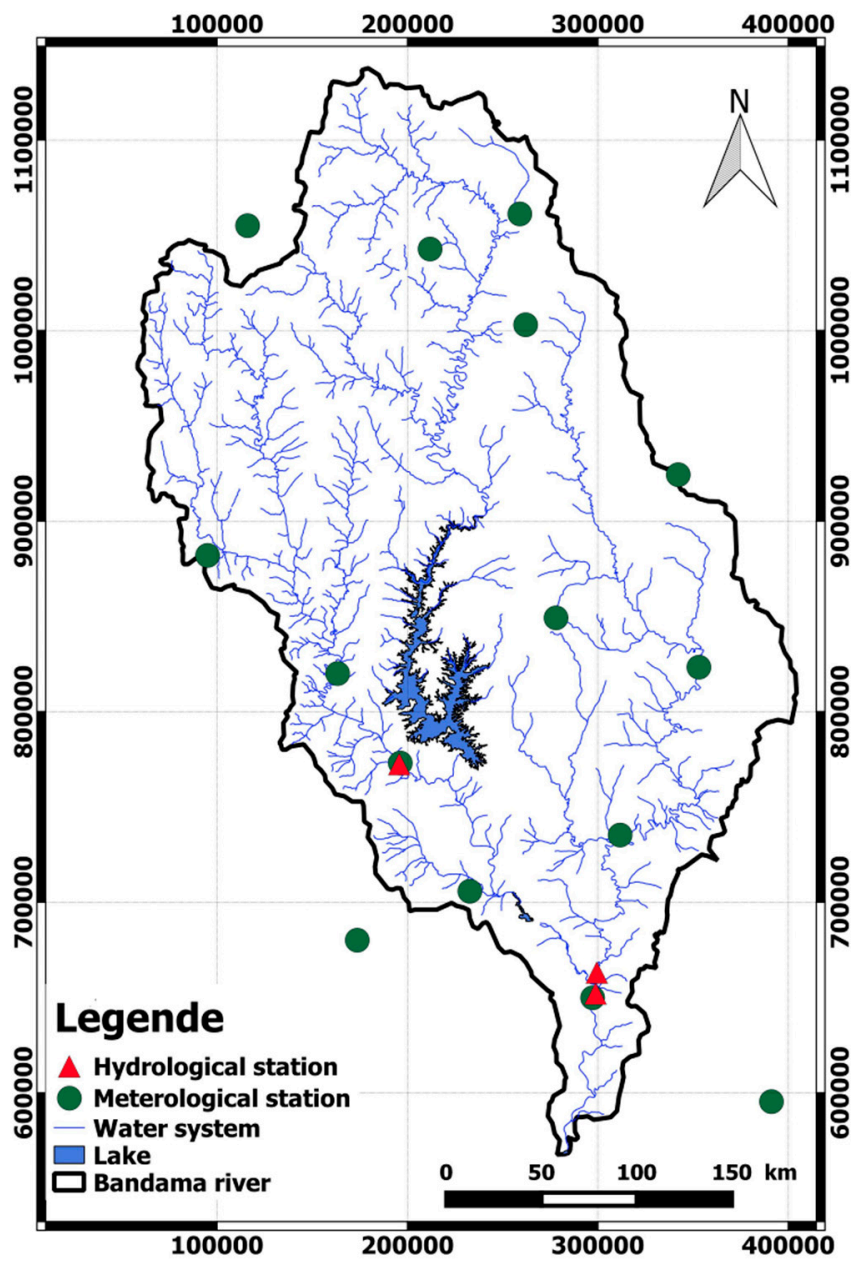

Figure 2. Network of meteorological and hydrological stations used in this study.

\subsubsection{Projected Future Climate Data}

Simulation results (monthly rainfall and temperature) for future climate from the HadGEM2-ES model were used. It is an Earth system model based on the HadGEM2 atmosphere-ocean general circulation model with additional representation of global-scale processes of biology and chemistry [24]. The simulations described here were driven by prescribed $\mathrm{CO}_{2}$ concentrations from the representative concentration pathways (RCPs) as part of the 5th Coupled Model Intercomparison Project [25]. The model used the RCP scenarios of changes in other anthropogenic greenhouse gases such as methane, nitrous oxide, and halocarbons, and anthropogenic aerosols such as sulfate and black carbon [26]. For this study, the RCP 4.5 and RCP 8.5 were used. RCP 4.5 is a scenario that stabilizes radiative forcing at 4.5 Watts per meter squared in the year 2100 without ever exceeding that value. This scenario is consistent with a future with relatively ambitious emission reductions. It is similar to SRES B1 [27]. Contrariwise, RCP 8.5 corresponds to a high greenhouse gas emissions pathway compared to the scenario literature. This RCP is consistent with a future with no policy changes to reduce emissions. It is comparable to the SRES A1F1 Emission Scenario [28].

The data used in this work are available from 1900-2100. The simulations were performed to monitor the climate in the short, medium, and long term on the following periods: 2006-2035, 2041-2060, and 2066-2085. The baseline period is 1986-2005. The choice of baseline period is due to the availability of the historical meteorological and hydrological data. Indeed, since 2006, the data transmission has been interrupted in a few stations. The data transmission was re-established in 2015 . 


\subsection{Methodology}

\subsubsection{Climate Change Simulations}

The differences between the climate (rainfall and temperature) of the baseline period and the future climate are calculated for each cell of the general circulation model (GCM) and for each time step (month $i$, year $j$ over the baseline period 1986-2005, and year $k$ over the 2006-2085 period). They are then expressed in change ratios (Horizons scenario) based on a mean climatology drawn from the HadGEM2-ES model simulations over the same baseline period. The change ratios of monthly rainfall and temperature between the baseline period and the three horizons, 2025 (2006-2035), 2050 (2036-2065), and 2075 (2066-2085), are calculated as:

$$
\Delta_{\text {horiz }, i}=100 \times\left(\bar{X}_{\text {horiz }, i}-\bar{X}_{r e f, i}\right) / \bar{X}_{r e f, i}
$$

where $\bar{X}_{\text {horiz }}$ is the mean value of the simulated series calculated over a given time horizon and $\bar{X}_{r e f}$ is the mean value of the simulated series calculated over the baseline period.

\subsubsection{Evaluation of Potential Climate Change Impacts on Water Resources}

\section{Climate Change Scenarios}

General circulation model (GCMs) often show bias in their simulation of the present climate. Various studies have shown that these models overestimate or underestimate the climatic parameters [29-33]. To reduce the estimation errors, it is recommended to build climate change scenarios. In this study, the deltas method proposed in [34] was used. The delta method used allows the implementation of two types of disturbances:

(1) Disturbances "additive" to the temperature:

$$
X_{a d d(t, m, y)}=X_{a c t(t, m, y)}+M_{c c(m)}-M_{r e f(m)}
$$

(2) Disturbances "multiplicative" to the rainfall:

$$
X_{m u l t(t, m, y)}=X_{a c t(t, m, y)} \times \frac{M_{c c(m)}}{M_{r e f(m)}}
$$

where $X_{a d d(t, m, y)}$ and $X_{m u l t(t, m, y)}$ are disturbed variables, $X_{a c t(t, m, y)}$ is a baseline variable, and $M_{c c(m)}$ and $M_{r e f(m)}$ are the monthly averages of the variable calculated from HadGEM2-ES simulations on the time horizons and baseline period. The disturbance of month $m$ is imputed to the current variable (i.e., observed) $X_{a c t}$, at all-time steps $t$ of the month, for all years.

Hydrological Modeling

The climate change scenarios are evaluated by means of the GR2M model to observe the impacts of rainfall and temperature changes on water resources in the Bandama river basin. The GR2M model is widely used for hydrological modeling of river basins in Sub-Saharan Africa [29-33,35]. The GR2M model is a spatially lumped and a monthly time-step model developed by IRSTEA [36]. The hydrological functioning of the model is based on two reservoirs: the production reservoir with capacity $X 1$ and the routing reservoir with a capacity of $60 \mathrm{~mm}$ controlled by parameter $X 2$. The hydrological balance of the model is defined by the five terms as:

$$
P=R+I+E T+\Delta S
$$

where $P$ is the rainfall, $R$ is the runoff at the outlet, $I$ is the infiltration, ET is the evapotranspiration (transpiration and direct evaporation), and $\Delta S$ is variation in the water in the basin. 
The model is run with monthly data of two climate parameters (the rainfall and the potential evapotranspiration) and the monthly discharge data of the watershed outlet. The implementation of the model consists of the determination of the two parameters $X 1$ and $X 2$ during a calibration period and then a validation where the representativeness of the two parameters is evaluated (different with the calibration period) [35]). GR2M is calibrated and validated through the Nash efficiency criterion [37]. For both periods (calibration and validation), the Nash efficiency should be higher than $60 \%$ for simulations with the optimum parameters. The efficiency criterion evaluates the representativeness of the simulated monthly discharges by the model from:

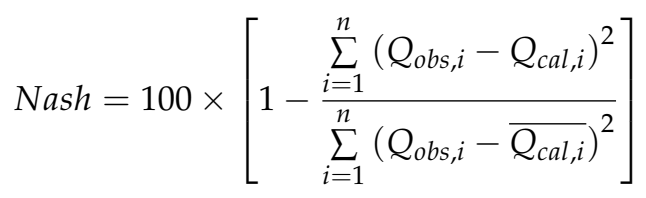

where $Q_{i \text { obs }}$ ios is the observed discharge for month $i, Q_{i \text { cal }}$ is the simulated discharge for month $i$, and $\bar{Q}_{c a l, i}$ is the mean observed discharge over the given period. A full description of the GR2M model is presented in [30].

\section{Results and Discussion}

\subsection{Assessment of the Changes in Climate Parameters}

\subsubsection{Changes in Temperatures}

The results showed that the temperatures from the Bandama basin will increase in the future (Figure 3). The findings are in accordance with the latest Intergovernmental Panel on Climate Change (IPCC) report. In this study, the temperature in all the months might increase in both the scenarios, but it will be higher in the RCP 8.5 than that in the RCP 4.5. The works of [38] identify tropical West Africa as a hotspot of climate change for both RCP 4.5 and RCP 8.5 pathways, and unprecedented climates are projected to occur earlier (late 2030s to early 2040s) in these regions. It shows that in RCP 8.5, the Bandama basin will experience a temperature rise of $1.5^{\circ} \mathrm{C}$ with the minimum temperature rise of about $1.2^{\circ} \mathrm{C}$ and a maximum of about $1.7^{\circ} \mathrm{C}$ by 2025 . The monthly temperatures may vary from $2.2^{\circ} \mathrm{C}$ to $3^{\circ} \mathrm{C}$ by 2050. A more pronounced increase in temperature is expected in 2066-2085, with annual temperature predictions approximately $20 \%$ higher than the baseline temperature. Under RCP 4.5 , changes in monthly temperatures may vary from by $0.9^{\circ} \mathrm{C}$ in July to $2{ }^{\circ} \mathrm{C}$ in January with an average annual of $2.5^{\circ} \mathrm{C}$ by 2025 . The temperature increases will be greater in the north (Ferkessedougou station) than in the south (Abidjan station) by the 2050's and 2075. Several works in West Africa show a warming range of 3 and $6{ }^{\circ} \mathrm{C}$ above the late 20th Century baseline [39-42]. As in the Bandama watershed, the work [43] has shown that the magnitude of temperature is higher for the higher emission scenarios of RCP 8.5 than for the medium-low emission scenarios of RCP 4.5.

\subsubsection{Changes in Rainfall}

The per cent changes in monthly rainfall based on ground-based observations and projected simulation from the HadGEM2-ES model are presented in the Figure 4. The rates of increase or decrease in rainfall are relatively more in RCP 8.5 than RCP 4.5 over the basin. Under RCP 8.5 and $\mathrm{RCP} 4.5$, the rainfall may decrease from December to April in future periods. This period corresponds to the long dry season in the basin. It is projected to decrease by $3 \%$ to $42 \%$ at all horizons under RCP 4.5 and by $5 \%$ to $47 \%$ under RCP 8.5 .

During the wet months (June-July and September-November) in all future periods, the rainfall may increase with respect to the reference period (1986-2005). The works of [44] show that the dry-season decrease ranges from $4 \%$ to $25 \%$ and the wet-season increase ranges from $5 \%$ to $23 \%$. However, the increase in the wet months' rainfall may be higher in the far future (2041-2060 or 
2066-2085) than in the near future (2006-2035). In West Africa, the rainfall season is predicted to be wetter and delayed by the end of the 21st Century [45]. Otherwise, the work in West Africa [33] showed that although the GCMs manage to reproduce these seasonal dynamics (except for HadCM3), they have real difficulty in accurately simulating the volume of rainfall.
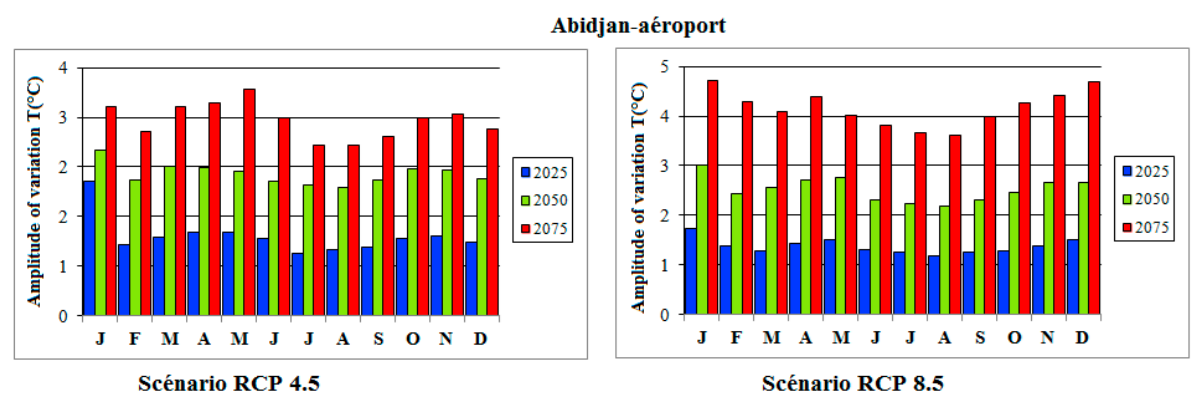

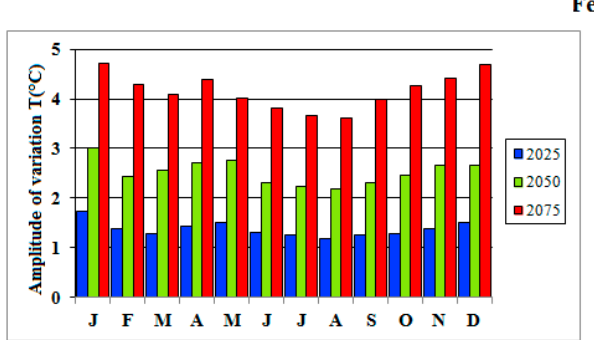

Scénario RCP 4.5

Ferkessédougou

Figure 3. Amplitude of variations in monthly temperatures at different horizons according to the HadGEM2-ES model in the Bandama basin.

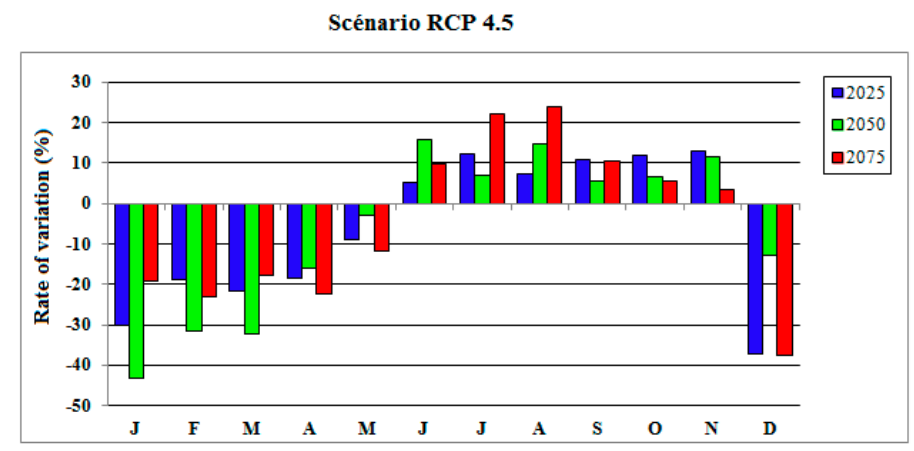

Scénario RCP 8.5

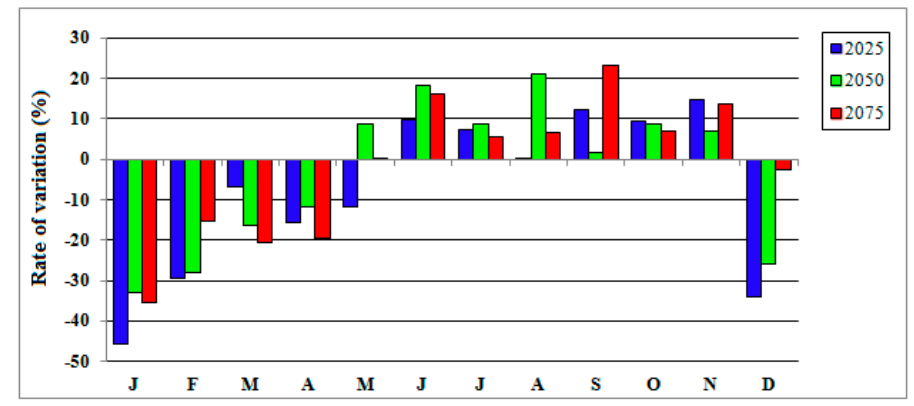

Figure 4. Percentage change in the monthly rainfall for the period 1978-2004 versus 1951-1977 in the Climate Research Unit (CRU) and University of Delaware (UD) observations (top left panels) and in each selected Coupled Model Intercomparison Project Phase 5 (CMIP5)model simulation in the Bandama basin. 


\subsection{Hydrological Model Calibration}

Impacts of climate on water resources were assessed using a hydrological model. The hydrological model GR2M calibration was performed for the periods 1980-1989 (N'zi river), 1980-1987 (Marahoué river), and 1969-1975 (Bandama river). Calibration is the process of choosing the best sets of model parameters, by automatically adjusting their numerical values to better mimic the response observed at the outlet. For these different periods, the Nash performance coefficients are $72.3 \%, 77.3 \%$, and $76.7 \%$ respectively (Table 2). Validating a model means to the check the reproducibility of the results by the calibrated parameters. The model validation was done using one period by selected river: 1990-1998 (N'Zi river), 1967-1977 (Marahoué river), and 1969-1975 (Bandama river). The results shows that the simulated and observed monthly runoffs are very similar with the Nash coefficients greater than $70 \%$ (Figure 5).

Table 2. Calibration and vadiation periods with Nash criteria value from the GR2M model.

\begin{tabular}{ccccc}
\hline \multirow{2}{*}{ River (Station) } & \multicolumn{2}{c}{ Calibration } & \multicolumn{2}{c}{ Validation } \\
\cline { 2 - 5 } & Period & Nash Criteria Value (\%) & Period & Nash Criteria Value (\%) \\
\hline Marahoué & $1980-1987$ & 72.3 & $1967-1977$ & 74.5 \\
(Bouaflé) & 77.3 & $1990-1998$ & 72.5 \\
N'Zi (Zianouan) & $1980-1989$ & 76.7 & $1981-1989$ & 78.4 \\
Bandama (Tiassalé) & $1969-1975$ & &
\end{tabular}
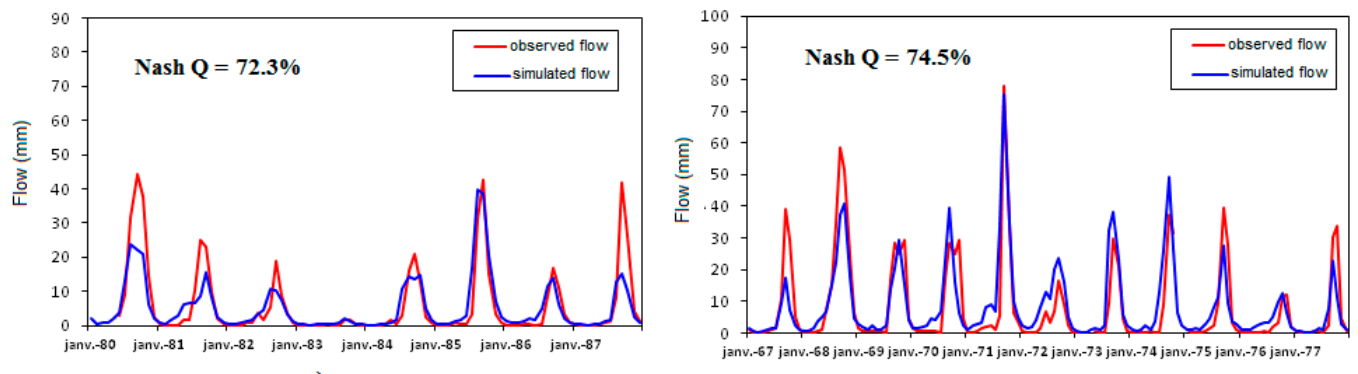

Marahoue river at Bouafle station

b)
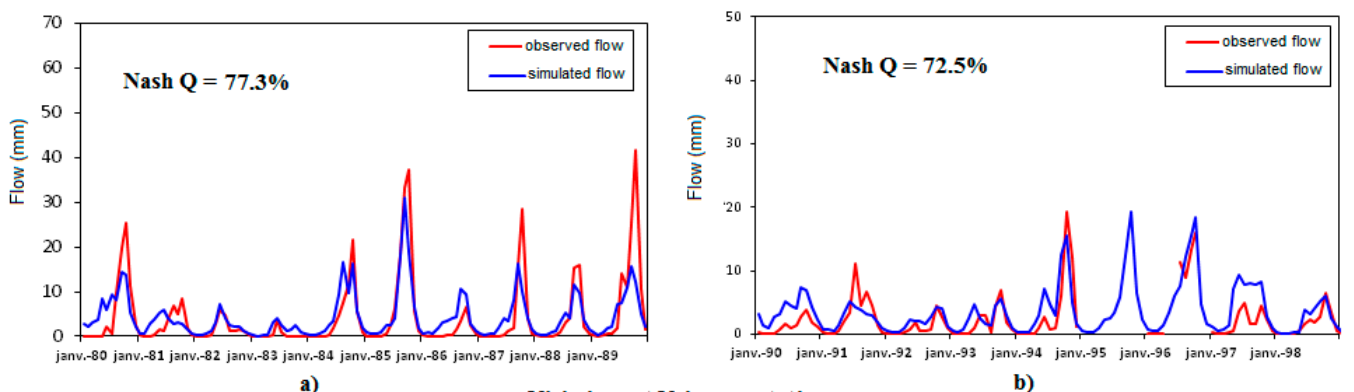

a)

N'zi river at Nzianoua station

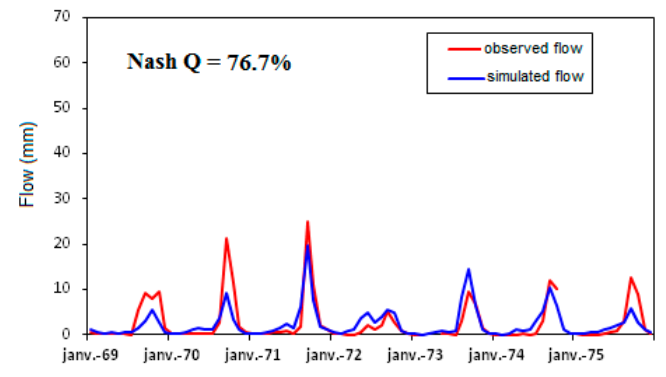

a)

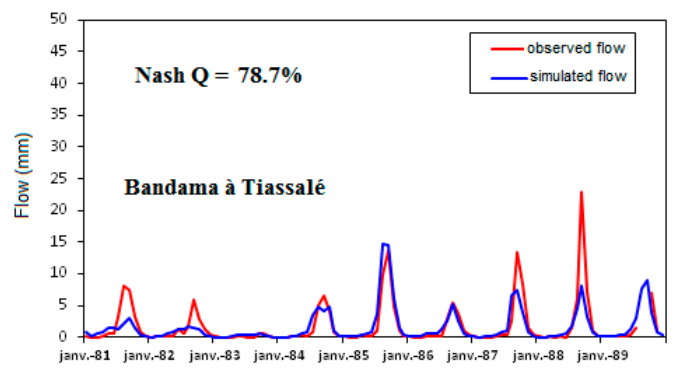

Bandama river at Tiassalé station

b)

Figure 5. Monthly flow from the observations and the simulations with GR2M with (a) representing the period of calibration and $(\mathbf{b})$ the validation period. 


\subsection{Impacts of Climate Change on Surface Water}

Comparison of the mean monthly hydrographs for the three time horizons with that of the baseline period shows that the annual hydrological pattern for the Bandama, Nzi, and the Marahoue catchments remains unchanged (Figure $6 a, b$ ). The changes caused by climate change affect runoff volume in the watershed. However, the trends in river discharge are different for each scenario. Under RCP 4.5, mean monthly runoff increases for all horizons. For the Marahoué and Bandama river, the changes are important from July to October. For the N'zi river, mean monthly runoff increases gradually from March to November. The findings are in accordance with the works of [31] on the Sassandra basin in Côte d'Ivoire under several scenario (A1, A2, B1, B2, A1B). Under RCP 8.5, runoff is projected to slightly decrease up to the horizon 2025, then to decrease at the horizons 2050 and 2075. Runoff is projected to vary mainly in tributary rivers. The works in the Comoé basin of [33] with the ReGcm model and A1 scenario, revealed a decrease in runoff of $18.8 \%$ to $34 \%$ in $2031-2040$ and $40 \%$ to $73 \%$ in the 2091-2100 horizon.
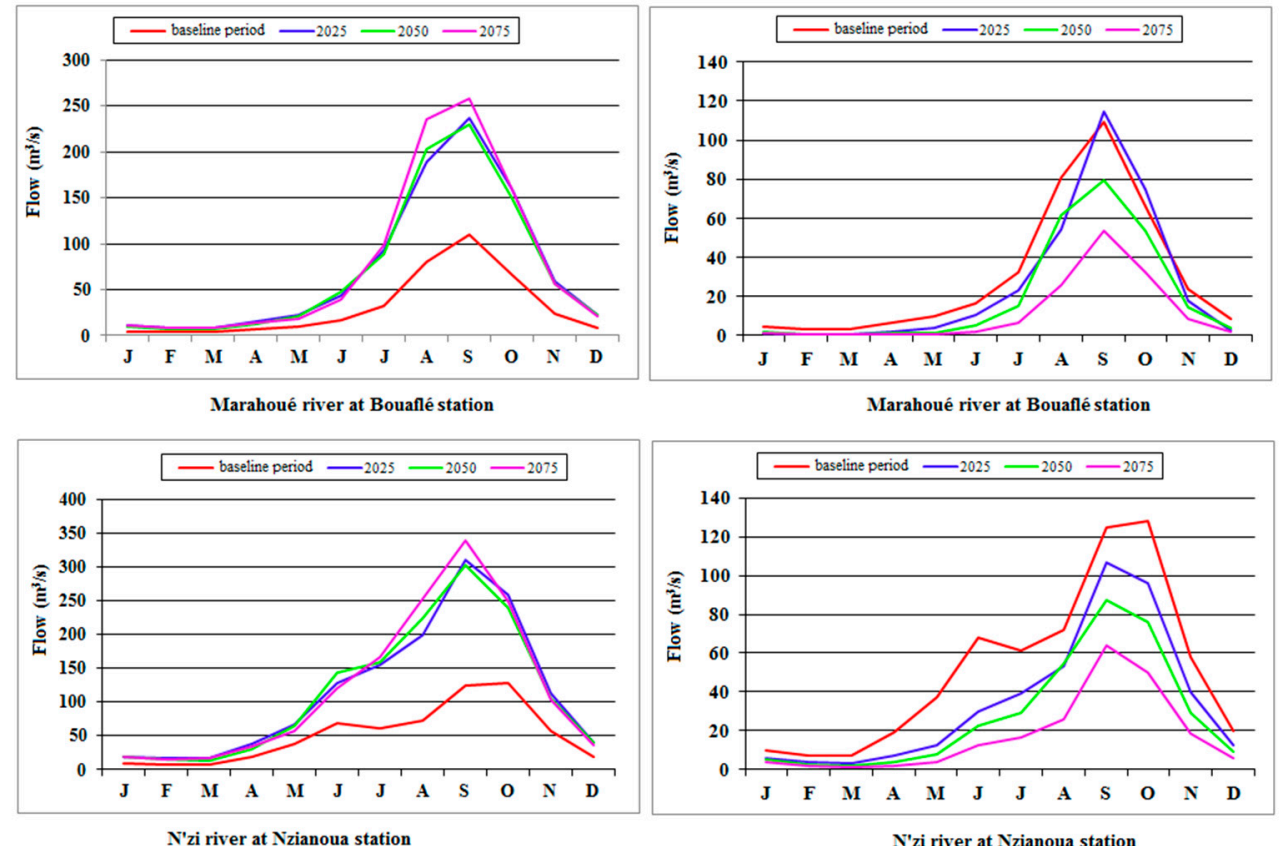

N'zi river at Nzianoua station
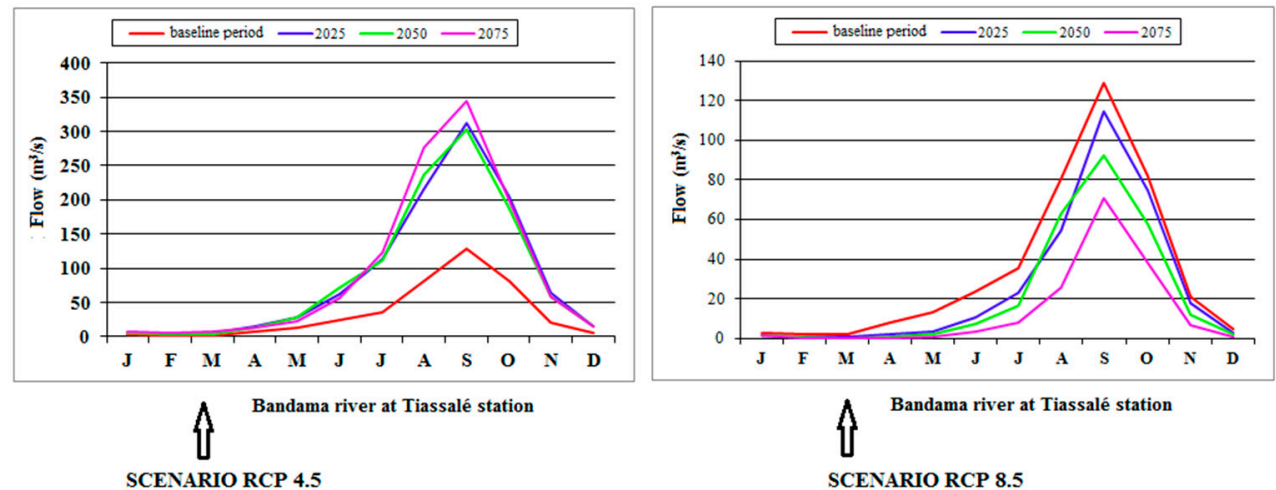

Figure 6. Monthly flows from the periods 1986-2005 (basline period), 2016-2035, 2041-2060, and 2066-2085 of the hydrological stations in the Bandama basin.

These results show that there is considerable uncertainty about the impacts of climate change on runoff. According to [45], overall projections of impacts of climate change on water resources in Sub-Saharan Africa are associated with large uncertainties. Apart from addressing the lack of 
observational data, key challenges for assessing climatic risks to water availability relate to their responses to heat waves, seasonal rainfall variability, as well as the relationship between land use changes, evapotranspiration, and soil moisture at different levels of global warming [43].

\subsection{Impacts of Climate Change on Groundwater}

Under RCP 8.4 and RCP 4.5, the climate change is likely to affect groundwater due to changes in precipitation and temperature. The sensitivity of groundwater recharge to climate change is shown in Figure 7. The scenarios under RCP 8.5 show that a trend towards increasing greenhouse gases may significantly decrease in groundwater recharge. The groundwater recharge may decrease from $136.6 \mathrm{~mm}$ to $73.8 \mathrm{~mm}$ by 2025 . By 2075 , groundwater may decrease from $60.2 \%$ to $55.4 \%$ compared to the baseline period. In the far future (2066-2095), the groundwater recharge may decrease in the Bandama aquifers. In the Comoé basin, infiltration could decrease by $7 \%$ to $13 \%$ in the $2031-2040$ horizon and $49.3 \%$ to $70 \%$ from 2091 to 2100 [26]. Contrary to RCP 8.5 , RCP 4.5 indicates climate change should induce an increase in groundwater recharge of the coming decades (Figure 7).

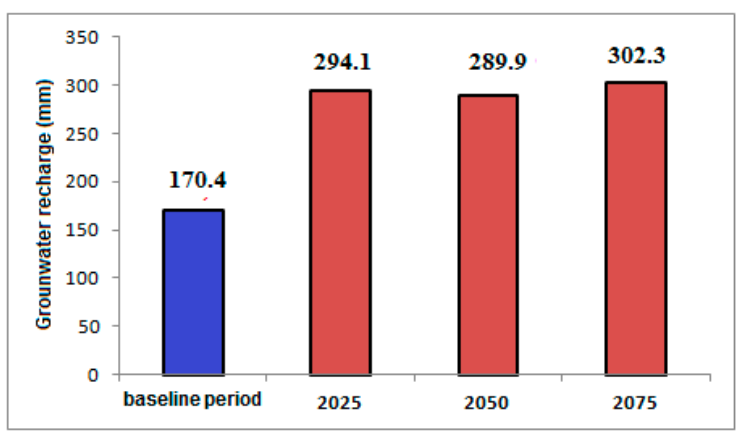

Marahoué river at Bouaflé station

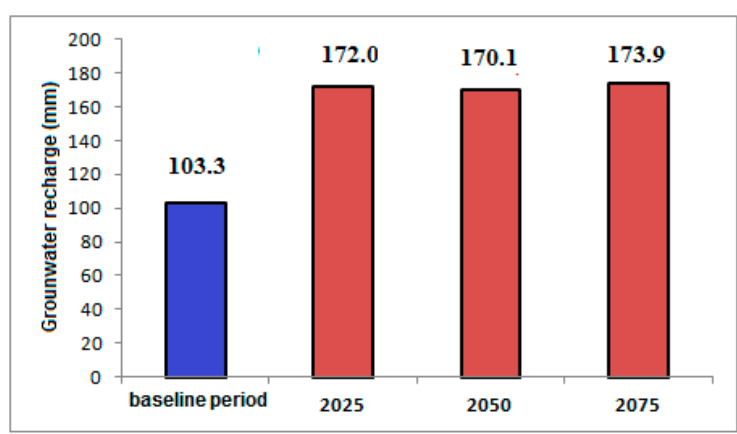

N'zi river at Zianouan station

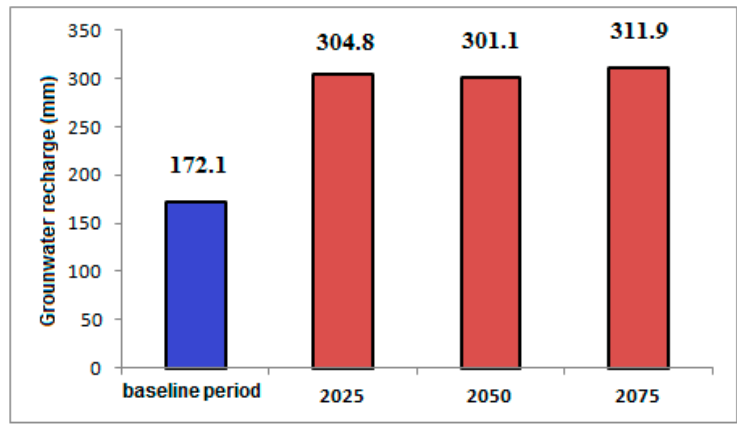

$\hat{\jmath}$

SCENARIO RCP 4.5

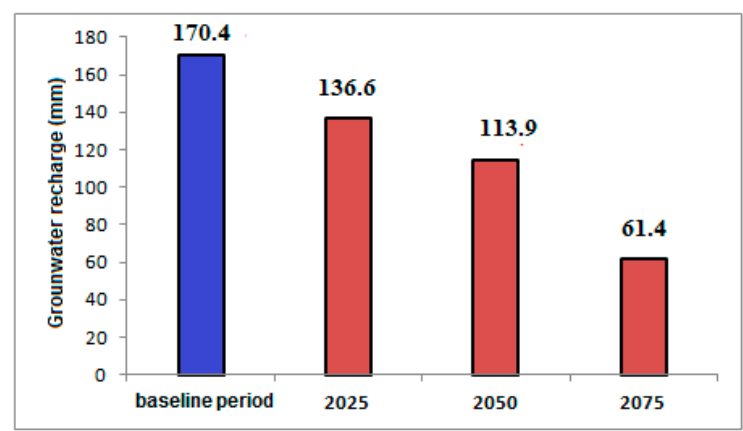

Marahoué river at Bouaflé station

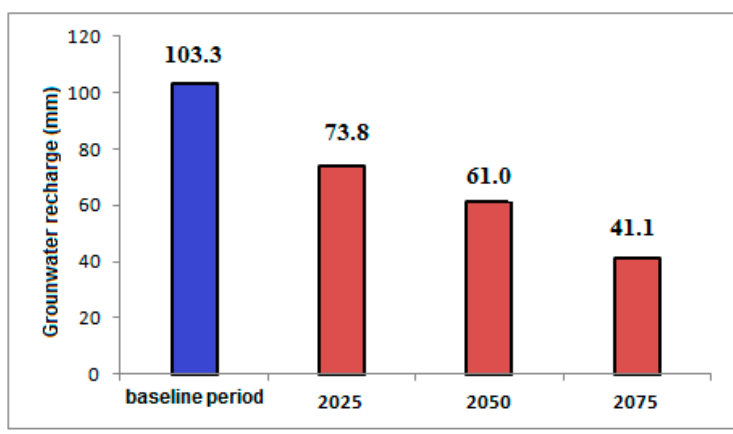

N'zi river at Zianouan station

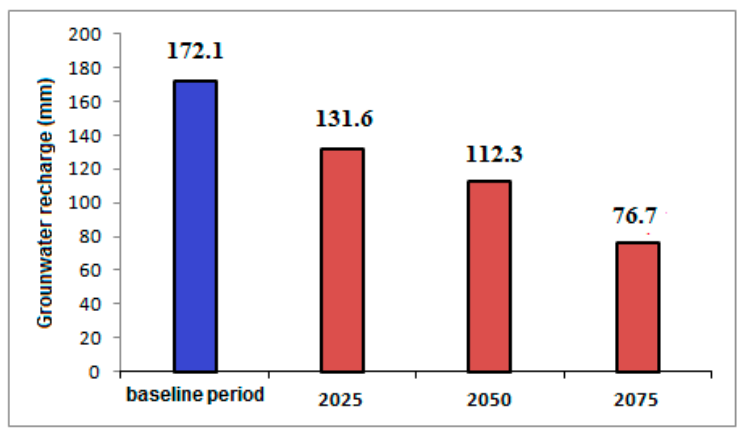

Đandama river at Tiassalé station

Figure 7. Evolution of annual average groundwater recharge in the Bandama basin. 


\section{Conclusions}

This paper showed that the Bandama basin is highly vulnerable to climate change. Indeed, analyses from this work showed that the temperature may increase and monthly rainfall may decrease from December to April in the future. In addition, the climate change analysis shows that the impacts are very different from RCP 4.5 to RCP 8.5. Under RCP 4.5, mean monthly runoff and groundwater recharge may increase for all horizons. Changes of runoffs and groundwater recharge are mainly dominated by the variations in projected precipitation. Especially in the long-term, increasing precipitation in the wet-season would make it wetter, resulting in higher runoff and aquifer recharge in the watershed. This phenomenon is due to the strong aquifer-river relationship on the basin. Indeed, the increase in aquifer levels would lead to an increase in the flow of watercourses supplied by the aquifers. On the other side, these two parameters may decrease for all horizons. These results highlight the large uncertainties associated with the impacts of climate change on water resources through global models (climatic and hydrological).

Acknowledgments: The authors thank the Department of Meteorology and Hydraulic Infrastructures division, Government of Côte d'Ivoire for data acquisition.

Author Contributions: Gneneyougo Emile Soro developed the ideas; Affoué Berthe Yao and Yao Morton Kouame contributed to the realization of the map and the data processing. Gneneyougo Emile Soro analyzed data and wrote the paper with inputs from Affoué Berthe Yao, Yao Morton Kouame, and Tié Albert Goula Bi.

Conflicts of Interest: The authors declare no conflict of interest.

\section{References}

1. Intergovernmental Panel on Climate Change. Special Report: Managing the Risks of Extreme Events and Disasters to Advance Climate Change Adaptation; Field, C.B., Barros, V., Stocker, T.F., Dahe, Q., Eds.; Cambridge University Press: Cambridge, UK, 2012.

2. Valipour, M. Necessity of irrigated and rainfed agriculture in the world. Irrig. Drain. Syst. Eng. 2013, S9, e001. [CrossRef]

3. Valipour, M. Need to update of irrigation and water resources information according to the progresses of agricultural knowledge. Agrotechnology 2013, S10, e001. [CrossRef]

4. Kurukulasuriya, P.; Mendelsohn, R. Modeling Endogenous Irrigation: The Impact of Climate Change on Farmers in Africa; Center for Environmental Economics and Policy in Africa (CEEPA) Discussion Paper N ${ }^{\circ}$; Special Series on Climate Change and Agriculture in Africa; World Bank Policy Research Working and University of Pretoria: Pretoria, South Africa, 2006.

5. Burlando, P.; Rosso, R. Effects of transient climate change on basin hydrology. 1. Precipitation scenarios for the Arno River, central Italy. Hydrol. Proc. 2002, 16, 1151-1175. [CrossRef]

6. Guo, S.; Wang, J.; Xiong, L.; Ying, A.; Li, D. A macro-scale and semi-distributed monthly water balance model to predict climate change impacts in China. J. Hydrol. 2002, 268, 1-15. [CrossRef]

7. Smith, J.B.; Schellnhuber, H.J.; Mirza, M.Q.; Fankhauser, S.; Leemans, R.; Erda, L.; Ogallo, L.; Pittock, B.; Richels, R.; Rosenzweig, C.; et al. Vulnerability to climate change and reasons for concern: A synthesis. In Climate Change 2001: Impacts, Adaptation, and Vulnerability; McCarthy, J., Canziana, O., Leary, N., Dokken, D., White, K., Eds.; Cambridge University Press: New York, NY, USA, 2001; pp. 913-967.

8. Kurukulasuriya, P.; Rosenthal, R. A Ricardian Analysis of the Impact of Climate Change on African Cropland; Policy Research Working Paper, No. 4305. World Bank: Washington, DC, USA, 2007. Avaliable online https: / /openknowledge.worldbank.org/handle/10986/7508License:CCBY3.0Unported (accessed on 20 December 2016).

9. Hassan, R.; Nhemachena, C. Determinants of African farmers' strategies for adapting to climate change: Multinomial choice analysis. Afr. J. Agric. Resour. Econ. 2008, 2, 83-104.

10. Roudier, P.; Ducharne, A.; Feyen, L. Climate change impacts on runoff in West Africa: A review. Hydrol. Earth Syst. Sci. 2014, 18, 2789-2801. [CrossRef]

11. Brown, M.E.; McCusker, B. Climate Change and Agriculture in Africa: Impact Assessment and Adaptation Strategies. Eos Trans. AGU 2008, 89, 474-474. [CrossRef] 
12. United Nations Development Programme. Programme d'Appui à la Réduction de la Pauvreté PNUD 2009-2013, Sous Programme Protection de l'Environnement et Gestion Durable des Ressources Naturelles (PGDRN); UNDP: Abidjan, Côte d'Ivoire, 2009; p. 19. (In French)

13. Soro, N.; Lasm, T.; Kouadio, B.H.; Soro, G.; Ahoussi, K.E. Variabilité du régime pluviométrique du sud de la Côte d'Ivoire et son impact sur l'alimentation de la nappe d'Abidjan. Sud-Sci. Technol. 2004, 14, 12-19.

14. Goula, B.T.A.; Savane, I.; Konan, B.; Fadika, V.; Kouadio, G.B. Impact de la variabilité climatique sur les ressources hydriques des bassins de N'Zo et N'Zi en Côte d'Ivoire (Afrique tropicale humide). Vertigo 2006, 1, 1-12. [CrossRef]

15. Kouassi, A.M.; Kouamé, K.F.; Koffi, Y.B.; Djé, K.B.; Paturel, J.E.; Oularé, S. Analyse de la variabilité climatique et de ses influences sur les régimes pluviométriques saisonniers en Afrique de l'Ouest: Cas du bassin versant du N'Zi (Bandama) en Côte d'Ivoire. Cybergéo 2010, 513, 29-In. (In French) [CrossRef]

16. Yao, A.B. Evaluation des Potentialités en eau du Bassin Versant de la Lobo en vue D'une Gestion Rationnelle (Centre-Ouest de la Côte D'ivoire). Ph.D. Thèse, Université Nangui Abrogoua, Abidjan, Côte d'Ivoire, 2015.

17. Otchoumou, K.F.; Saley, M.B.; Aké, G.E.; Savane, I.; Djê, K.B. Variabilité climatique et production de café et cacao dans la zone tropicale humide: Cas de la région de Daoukro (Centre-Est de la Côte d'Ivoire). Int. J. Innov. Appl. Stud. 2012, 1, 194-215.

18. Sorokoby, V.M.; Saley, M.B.; Kouamé, K.F.; Djagoua, E.M.V.; Affian, K.; Biemi, J. Variabilité spatio-temporelle des paramètres climatiques et son incidence sur le tarissement dans les basins versants de Bô et Debo (département de Soubré au Sud-Ouest de la Côte d'Ivoire). Int. J. Innov. Appl. Stud. 2013, 2, 287-299.

19. Kouamelan, A.N. Géochronologie et Géochimie de Formations Archéennes et Protérozoïques de la Dorsales de Man en Côte D'ivoire: Implication Pour la Transition Archéen-Protérozoïque. Ph.D. Thèse, Université de Renne, Rennes, France, 1996.

20. Lemoine, S. Evolution Géologique de la Région de Dabakala (NE de la Côte D’Ivoire) au Protérozoïque Inférieur. Possibilité D'extension au Reste de la Côte D'ivoire et au Burkina Faso: Similitudes et Différences; les Linéaments Greenville-Ferkessédougou et Grand Cess-Niankaramadougou. Ph.D. Thèse, Université Blaise Pascal (Clermont Ferrand II), Aubière, France, 1998.

21. Biémi, J. Contribution à L'étude Géologique, Hydrogéologique et par Télédétection des Bassins Versants Subsaheliens du Socle Précambrien d'Afrique de L'ouest: Hydrostructurale, Hydrodynamique, Hydrochimie et Isotopie des Aquifères Discontinus de Sillons et Aires Granitiques de la Haute Marahoué (Côte D'Ivoire) D'Abidjan. Ph.D. Thèse, Naturelles Université Nationale, Abidjan, Côte d'Ivoire, 1992.

22. Kouakou, E.; Koné, B.; N'Go, A.; Cissé, G.; Ifejika Speranza, C.; Savané, I. Ground water sensitivity to climate variability in the white Bandama basin, Ivory Coast. SpringerPlus 2014, 3, 226. [CrossRef] [PubMed]

23. Amani, K.M. Caractérisation D'une Modification Éventuelle de la relation pluie-débit et Ses Impacts Sur les Ressources en eau en Afrique de L'Ouest: Cas du Bassin Versant du N'zi (Bandama) en Côte D'Ivoire. Ph.D. Thèse, Université de Cocody, Abidjan, Côte d'Ivoire, 2007.

24. Martin, G.M.; Bellouin, N.; Collins, W.J.; Culverwell, I.D.; Halloran, P.R.; Hardiman, S.C.; Hinton, T.J.; Jones, C.D.; McDonald, R.E.; McLaren, A.J.; et al. The hadGEM2 family of met office unified model climate configurations. Geosci. Model Dev. 2011, 4, 723-757.

25. Taylor, K.; Stouffer, R.; Meeh, G. An overview of cmip5 and the experiment design. Bull. Am. Meteorol. Soc. 2012, 93, 485-498. [CrossRef]

26. Betts, R.A.; Golding, N.; Gonzalez, P.; Gornall, J.; Kahana, R.; Kay, G.; Mitchell, L.; Wiltshire, A. Climate and land use change impacts on global terrestrial ecosystems and river flows in the HadGEM2-ES Earth system model using the representative concentration pathways. Biogeosciences 2015, 12, 1317-1338. [CrossRef]

27. Van Vuuren, D.; Edmonds, J.; Kainuma, M.; Riahi, K.; Thomson, A.; Hibbard, K.; Hurtt, G.; Kram, T.; Krey, V.; Lamarque, J.F.; et al. The representative concentration pathways: An overview. Clim. Chang. 2011, 109, 5-31. [CrossRef]

28. Riahi, K.; Rao, S.; Krey, V.; Cho, C.; Chirkov, V.; Guenther, F.; Georg, K.; Nakicenovic, N.; Rafaj, P. RCP 8.5-A scenario of comparatively high greenhouse gas emissions. Clim. Chang. 2011, 109, 33. [CrossRef]

29. Ardoin, B.S. Variabilité Hydroclimatique et Impacts sur les Ressources en eau de Grands Bassins Hydrographiques en Zone Soudano-Sahélienne. Ph.D. Thèse, Université de Montpellier II, Montpellier, France, 2004. 
30. Sighomnou, D. Analyse et Redéfinition des Régimes Climatiques et Hydrologiques du Cameroun: Perspectives D'évolution des Ressources en eau. Ph.D. Thèse, Université de Yaoundé I, Yaounde, Cameroun, 2004.

31. Ardoin-Bardin, S.; Dezetter, A.; Servat, E.; Paturel, J.E.; Mahé, G.; Niel, H.; Dieulin, C. Using general circulation model outputs to assess impacts of climate change on runoff for large hydrological catchments in West Africa. Hydrol. Sci. J. 2009, 54, 77-89. [CrossRef]

32. Kouakou, K.E. Impacts de la Variabilité Climatique et du Changement Climatique sur les Ressources en eau en Afrique de L'ouest: Cas du Bassin Versant de la Comoé. Ph.D. Thèse, Université Abobo-Adjamé, Abidjan, Côte d'Ivoire, 2011.

33. Kouakou, K.E.; Goula, B.T. A.; Kouassi, A.M. Analyze of climate variability and change impacts on hydro-climate parameters: Case study of Côte d'Ivoire. Int. J. Sci. Eng. Res. 2012, 3, 1-8.

34. Ducharne, A.; Théry, S.; Viennot, P.; Ledoux, E.; Gomez, E.; Déqué, M. Influence du changement climatique sur l'hydrologie du bassin de la Seine. VertigO 2003, 4. [CrossRef]

35. Ibrahim, B.; Karambiri, H.; Polcher, J. Hydrological Impacts of the Changes in Simulated Rainfall Fields on Nakanbe Basin in Burkina Faso. Climate 2015, 3, 442-458. [CrossRef]

36. Institut National de Recherche en Sciences et Technologies Pour L'environnement et L'agriculture. Available online: http:/ / www.irstea.fr/ (accessed on 20 March 2016).

37. Nash, J.; Sutclie, J. River flow forecasting through conceptual models. Part I: A discussion of principle. J. Hydrol. 1970, 10, 282-290. [CrossRef]

38. Diffenbaugh, N.S.; Giorgi, F. Climate change hotspots in the CMIP5 global climate model ensemble. Clim. Chang. 2012, 114, 813-822. [CrossRef] [PubMed]

39. Meehl, G.A.; Stocker, T.F.; Collins, W.D.; Friedlingstein, P.; Gaye, A.T.; Gregory, J.M.; Kitoh, A.; Knutti, R.; Murphy, J.M.; Noda, A.; et al. Global Climate Projections. In Climate Change; Solomon, S., Qin, D., Manning, M., Chen, Z., Marquis, M., Averyt, K.B., Tignor, M., Miller, H.L., Eds.; The Physical Science Basis; Contribution of Working Group I to the Fourth Assessment Report of the Intergovernmental Panel on Climate Change; Cambridge University Press: Cambridge, UK; New York, NY, USA, 2007.

40. Diallo, I.; Sylla, M.B.; Giorgi, F.; Gaye, A.T.; Camara, M. Multimodel GCM-RCM ensemble-based projections of temperature and precipitation over West Africa for the early 21st century. Hindawi Publishing Corporation. Int. J. Geophys. 2012. [CrossRef]

41. Monerie, P.A.; Fontaine, B.; Roucou, P. Expected future changes in the African monsoon between 2030 and 2070 using some CMIP3 and CMIP5 models under a medium-low RCP scenario. J. Geophys. Res. Atmos. 2012, 117, 1-12. [CrossRef]

42. Niang, I.; Ruppel, O.C.; Abdrabo, M.A.; Essel, A.; Lennard, C.; Padgham, J.; Urquhart, P. Africa. In Climate Change 2014: Impacts, Adaptation, and Vulnerability; Part B: Regional Aspects; Contribution of Working Group II to the Fifth Assessment Report of the Intergovernmental Panel on Climate Change; Cambridge University Press: Cambridge, UK, 2014.

43. Ayele, H.S.; Li, M.-H.; Tung, C.-P.; Liu, T.-M. Impact of Climate Change on Runoff in the Gilgel Abbay Watershed, the Upper Blue Nile Basin, Ethiopia. Water 2016, 8, 380. [CrossRef]

44. Christensen, J.H.; Hewitson, B.; Busuioc, A.; Chen, A.; Gao, X.; Held, I.; Jones, R.; Koli, R.K.; Kwon, W.-T.; Laprise, R.; et al. Regional climate projections. In Climate Change 2007: The Physical Science Basis. Contribution of Working Group I to the Fourth Assessment Report of the Intergovernmental Panel on Climate Change; Solomon, S., Qin, D., Manning, M., Chen, Z., Marquis, M., Averyt, K.B., Tignor, M., Miller, H.L., Eds.; Cambridge University Press: Cambridge, UK, 2007; pp. 847-940.

45. Serdeczny, O.; Adams, S.; Baarsch, F.; Coumou, D.; Robinson, A.; Hare, W.; Schaeffer, M.; Perrette, M.; Reinhardt, J. Climate change impacts in Sub-Saharan Africa: From physical changes to their social repercussions. Reg. Environ. Chang. 2015, 1-16. [CrossRef]

(C) 2017 by the authors. Licensee MDPI, Basel, Switzerland. This article is an open access article distributed under the terms and conditions of the Creative Commons Attribution (CC BY) license (http:/ / creativecommons.org/licenses/by/4.0/). 